Kumawula, Vol. 2, No.3, Desember 2019, Hal 262 - 269 DOI:http://10.24198/kumawula.v1i3.24592

ISSN 2620-844X (online)

Tersedia online di http://jurnal.unpad.ac.id/kumawula/index

\title{
PEMBERDAYAAN KEWIRAUSAHAAN MASYARAKAT DESA CISEMPUR DAN PENDAMPINGAN KEWIRAUSAHAAN BERBASIS ECOMMERCE
}

\author{
Nina Karlina ${ }^{*}$, Hilman Abdul Halim ${ }^{2}$, Muhammad Furqon Azizi ${ }^{3}$, Annisa Athusholihah ${ }^{4}$, \\ Anisa Tarliyah ${ }^{5}$ \\ 1,2,3,4,5 KKN Kewirausahaan Desa Cisempur. Kacamatan Jatinangor, Universitas Padjadjaran, \\ Kabupaten Sumedang \\ *nina.karlina@unpad.ac.id
}

\begin{abstract}
ABSTRAK
Kuliah Kerja Nyata (KKN) Tematik Kewirausahaan merupakan sebuah kegiatan pengabdian kepada masyarakat yang melibatkan mahasiswa sebagai peserta dan dosen sebagai pembimbing yang berfokus pada tema kewirausahaan. Kegiatan KKN di Desa Cisempur, Kecamatan Jatinangor Kabupaten Sumedang selama 2 minggu memfokuskan pada pengembangan Usaha Mikro Kecil Menengah (UMKM) yang masih perlu untuk dikembangkan sebagai bentuk pemberdayaan demi terciptanya kesejahteraan masyarakat. Permasalahan yang ditemui di desa Cisempur, potensi masyarakat dalam berwirausaha masih kurang sehingga perlu dimotivasi agar masyarakat mempunyai jiwa kewirausahaan. Pendampingan diberikan kepada salah satu wirausaha yang berpotensi berkembang dan sosialisasi mengenai kewirausahaan di lakukan kepada ibu2 PKK dan masyarakat secara umum yang sudah berwirausaha maupun belum. Peserta yang hadir kurang lebih sebanyak 50 orang. Tujuan Sosialisasi adalah memberikan pemahaman, bimbingan dan seminar kepada masyarakat terkait cara menumbuhkan jiwa kewirausahaan dan e-commerce. Hasil dari rangkain kegiatan pengabdian ini adalah pengembangan salah satu produk makanan kecil seblak kering dengan kemasan dan pemasaran yang lebih modern. Pelaksanaan talkshow pemberdayaan jiwa kewirausahaan menbuat tumbuhnya kesadaran serta jiwa kewirausahaan pada diri mahasiswa maupun masyarakat guna siap bersaing pada era percepatan ilmu pengetahuan dan teknologi. Rekomendasi yang dapat kami berikan kepada masyarakat Desa Cisempur adalah pemanfaatan internet guna mengejar ketertinggalan pada pasar digital. Juga sangat diharapkan meningkatnya kepercayaan diri pada setiap wirausaha yang tengah merintis usahanya
\end{abstract}

Kata Kunci: Pemberdayaan, jiwa kewirausahaan, pendampingan kewirausahaan, e commerce

\section{ABSTRACT}

Entrepreneurship themed social service is a social service that involves university students as participants and lecturers as advisers. The program was held for 2 weeks in Cisempur Village, Jatinangor Sub-District, Sumedang District which focuses on developing Usaha Mikro Kecil Menengah (UMKM) that is still needed in order to empower the public and attain public welfare. The problems identified in Cisempur village include the fact that the public has little entrepreneurship desires, 
therefore there needs to be motivation in order to build that desire. We accompany the PKK women and others that have or have not started their entrepreneurship efforts. The participants that attended was around 50 people. The target of the socialization was to give understanding, guidance, and a seminar towards the public regarding how to build an entrepreneurial and e-commerce centered spirit. The results of these activities was the development of the "seblak kering" snack with a more modern packaging and marketing strategy. The talk show regarding entrepreneurial spirit inside students and the public was held in order to prepare them for a new era of knowledge and technology. We recommend to the residents of Cisempur Village to use the internet wisely in order to catch up to a digital marketplace. We also hope that the entrepreneurs gain self confidence when building their businesses.

Keywords: Empowerment, Entrepreneurial spirit, Entrepreneurial guidance, e-commerce

\section{PENDAHULUAN}

Kegiatan KKN Tematik Kewirausahaan ini merupakan salah satu cara untuk mengembangkan kreativitas mahasiswa dalam membantu dan terjun langsung melihat permasalahan yang ada di masyarakat khusunya dalam kewirausahaan. Dalam praktiknya, kegiatan KKN Tematik Kewirausahaan merupakan media mempraktikan ilmu yang didapat dari perkuliahan, ataupun ilmu baru yang bersifat formal dan informal yang didapatkan dari masyarakat. KKN Tematik Kewirausahaan ini dapat membantu perubahan desa dan memaksimalkan potensi warganya yang sudah ataupun memiliki potensi usaha untuk lebih terbuka lagi dengan perkembangan ilmu pengetahuan dan teknologi sehingga nantinya akan tumbuh para wirausaha di desa yang membuat desa itu semakin maju dan berkembang sesuai juga dengan harapan pemerintah yaitu "One Village One Company" dengan bantuan mahasiswa harapannya bisa terwujud dengan seksama .Adapun KKN Tematik Kewirausahaan di Universitas Padjadjaran lebih terfokus ke daerah yang berada di Jawa Barat khusunya wilayah kabupaten sumedang karena hal ini merupakan salah satu kontribusi dari program "Unpad Nyaah Ka Jabar".

Salah satu desa yang menjadi fokus dari KKN Tematik Kewirausahaan ini yaitu Desa Cisempur. Desa Cisempur merupakan sebuah desa yang berada di wilayah Kecamatan Jatinangor, Kabupaten Sumedang . Lokasinya berada du ujung timur kecamatan, tepatnya di bagian tenggara wilayah Kecamatan Jatinangor. Wilayahnya berada di perbatasan Kecamatan Jatinangor dengan Kecamatan Cimanggung. Jarak dengan pusat kecamatan sekitar lima kilometer, atau jarak terjauh jika dibandingkan dengan desa-desa lainnya yang berada di wilayah Kecamatan Jatinangor.

Secara geografis, wilayah Desa Cisempur dikelilingi oleh wilayah-wilayah sebagai berikut: Desa Jatimukti dan Desa Jatiroke di sebelah utara, Desa Sawahdadap dan Desa Mangunraga (kedua berlokasi di Kecamatan Cimanggung) di sebelah timur, Desa Mangunraga 
Kecamatan Cimanggung di sebelah selatan, serta Desa Cinta Mulya di sebelah baratnya. Sementara secara administratif, wilayah Desa Cisempur terbagi ke dalam sepuluh Rukun Warga dan 31 Rukun Tetangga.

\section{METODE PELAKSANAAN}

Kegiatan yang dilakukan dalam program KKN Kewirausahaan ini adalah membantu masyarakat Desa Cisempur dalam mengembangkan potensi usaha yang ada. Dalam hal ini pertama-tama kegiatan yang kami lakukan adalah melakukan wawancara kepada aparat desa mengenai demografis, kependudukan, dan keadaan lingkungan di desa Cisempur.

Observasi yang kami lakukan diberbagai wilayah di desa Cisempur ini menghasilkan bahwa potensi yang ada pada desa Cisempur ini diantaranya pengusaha pindang, makanan ringan, pabrik tempe, pabrik siomay, konveksi, penjual bibit tanaman cabe, dan berbagai usaha pertanian lainnya.

Menurut hasil diskusi kelompok kami usaha yang akan kami bantu kembangkan adalah usaha seblak kering milik ibu Heni yang bertempat di RT 01 RW 10 desa Cisempur. Menurut kami usaha ini mempunyai peluang untuk berkembang namun ada beberapa hal yang harus dievaluasi dan juga dikembangkan. Usaha milik bu Heni ini juga memiliki kendala dalam hal permodalan terkadang beliau tidak berjualan dikarenakan modal yang kurang memadai, dalam hal ini peran desa sangatlah penting. Tidak adanya BUMDES dalam sistem desa menjadikan salah satu faktor masyarakat menjadi terhalang dalam mengembangkan potensi usahanya.

Selanjutnya kami melihat proses pembuatan hingga pengepakan seblak kering usaha bu Heni. Dalam hal ini kami memberikan masukan mengenai pemakaian sarung tangan dalam pembuatan agar tidak terjadi kontaminasi dan penyebaran penyakit, kemudian alat-alat yang digunakan juga masih sederhana maka diperlukan alat-alat yang mampu membuat usaha bu heni lebih cepat dalam proses pembuatannya seperti serok untuk memasukkan seblak kedalam kemasan dan alat sealer untuk perekat plastik.

Kemasan yang digunakan juga masih kurang menarik, serta usaha bu Heni belum memiliki brand tersendiri. Maka dari itu kami membantu usaha bu Heni dengan membantu memikiran dan mencoba membuatkan kemasan yang lebih menarik. Selain itu juga dalam proses pemasaran usaha seblak kering ini masi sangat minim, maka dari itu kami mencoba untuk memasarkan usaha seblak kering bu Heni ini secara online baik di web, dan toko-toko online lain seperti tokopedia dan buka lapak. 
Berdasarkan dari kondisi Bu Heni, maka tim KKN melihat bahwa masalah utamanya adalah bagaimana membantu membuka dan mengembangkan pola pikir, motivasi, pembelajaran serta pengalaman mengenai kewirausahaan pada masyarakat desa cisempur. Karena potensi mereka ada tapi belum percaya diri mengembangkan usahanya lebih besar, apalagi menerapkan teknologi yang sedang berkembang saat ini, sehingga kita memandang perlu untuk melakukan "Sosialisasi Pemberdayaan jiwa Kewirausahaan dan Pendampingan kewirausahaan berbasis e-commerce"

Tujuan kegiatan:

1. Memberikan pengetahuan yang diperlukan kepada masyarakat mengenai wirausaha yang berdaya saing dengan iptek serta market place

2. Memberikan pemahaman, bimbingan dan seminar kepada masyarakat terkait cara menumbuhkan jiwa kewirausahaan dan e-commerce

Manfaat kegiatan:

Edukasi dan seminar yang dilaksanakan dapat bermanfaat untuk menumbuhkan jiwa para wirausaha ,serta dapat mengembangkan para wirausaha untuk berdaya saing lebih luas dengan melalui market place yang akan memberikan dampak yang cukup signifikan bagi desa sehingga mengurangi beberapa permasalahan ekonomi berupa kemiskinan,pengangguran dan yang lainnya .

\section{HASIL DAN PEMBAHASAN}

Terkait tentang mata pencahariannya, dengan adanya perubahan orientasi wilayah Desa Cisempur mempengaruhi juga orientasi mata pencaharian penduduknya. Orientasi Desa Cisempur berubah menjadi kawasan industri. Yang sebelumnya merupakan kawasan pertanian. Sehingga terjadi perubahan mata pencaharian penduduk Desa Cisempur dari sektor pertanian ke sektor industri. sebagian besar penduduk Desa Cisempur bekerja di sektor industri disamping sektor jasa dan perdagangan. Dan juga banyak yang bekerja di sektor pertanian dengan adanya lahan pertanian yang cukup luas.

Keluhan yang dirasakan oleh masyarakat desa cisempur diantaranya yaitu, kekeringan yang disebabkan oleh kemarau Panjang, sulitnya pasokan air besih berdampak pada produktivitas dan aktivitas masyarakat di desa tsb, juga angka kriminalitas tinggi karena SDM yang kurang, sulitnya mendapat pekerjaan, serta kurangnya dukungan pendidikan moral. 
Kegiatan yang telah dilakukan dalam program KKN Tematik Kewirausahaan adalah pengidentifikasian serta pengembangan UMKM yang memiliki potensi di Desa Cisempur. Tujuan dari kegiatan ini adalah guna meningkatkan pemberdayaan serta kesejahteraan masyarakat melalui kewirausahaan. Yang selanjutnya diharapkan masyarakat Desa Cisempur dapat menjadi masyarakat yang mandiri dan dapat bersaing pada era modern ini. Dari beberapa UMKM yang telah kami identifikasi di Desa Cisempur didominasi oleh jenis usaha konveksi serta pertanian. Sedangkan untuk usaha jenis olahan makanan masih sangat minim berkembang namun terlihat adanya potensi yang mumpuni untuk dikembangkan. Oleh karena itu, kami telah bersepakat untuk mengembangkan salah satu UMKM olahan makanan milik Ibu Heni Kurnia yakni beragam jenis makanan ringan seperti kerupuk seblak kering dan makaroni. Pengembangan yang kami lakukan yakni dalam hal branding serta marketing produk.

Peluang bisnis Seblak Kering Kurnia Snack sangat menjanjikan di Jatinangor karena diminati oleh banyak mahasiswa. Hal ini mengingat terdapat tiga kampus besar di wilayah Jatinangor. Para mahasiswa suka menikmati camilan tersebut di tengah berbagai kesibukannya. Produk ini dapat menjadi pilihan mahasiswa karena harganya yang terjangkau, terdapat banyak pilihan rasa, dan kemasannya mudah dibawa.

Dari hasil pengamatan, belum ada produk camilan sejenis yang memiliki varian rasa sebanyak Kurnia Snack. Dengan kondisi seperti ini, maka UMKM berpeluang untuk dikembangkan.

\section{Prioritas Masalah}

Berdasarkan penjelasan di atas, UMKM Kurnia Snack merupakan usaha yang memiliki potensi untuk dikembangkan lebih luas. Namun, di sisi lain, usaha ini masih memiliki beberapa kendala. Salah satu kendala yang dihadapi dalam bisnis ini adalah keberadaan kompetitor yang menjalankan bisnis sejenis. Kendala lain adalah kurangnya kepercayaan diri dan motivasi kewirausahaan dari pemilik UMKM ini. Oleh karena itu, untuk bisa mengembangkan usaha ini diperlukan branding yang kuat untuk membedakan produk Kurnia Snack dengan kompetitor lainnya, mengadakan bimbingan kewirausahaan terhadap pemilik bisnis serta pemberdayaan ibu - ibu Desa Cisempur.

\section{Manfaat Kegiatan}

Manfaat dari usaha Snack Kurnia ini diantaranya terbuka lapangan pekerjaan untuk ibu - ibu Desa Cisempur sehingga dapat meningkatkan produktivitas dan kemampuan 
mereka. Selain itu, ibu - ibu Desa Cisempur juga akan mendapatkan keuntungan finansial yang dapat membantu keuangan keluarga - keluarga di Desa Cisempur. Dengan membuka mitra kerja sama dengan warung - warung di wilayah Jatinangor, usaha ini juga memberikan keuntungan finansial masyarakat di Jatinangor.

\section{Luaran}

Produk yang dihasilkan dari usaha Kurnia Snack ini adalah kerupuk gelung, makaroni kering, seblak kering, basreng dan lumpia kering dengan berbagai varian rasa. Untuk membedakan produk Kurnia Snack dengan produk sejenis yang di pasaran ialah adanya varian rasa yang lebih beragam dan bisa disesuaikan dengan pesanan, serta kemasan yang sederhana namun menarik.

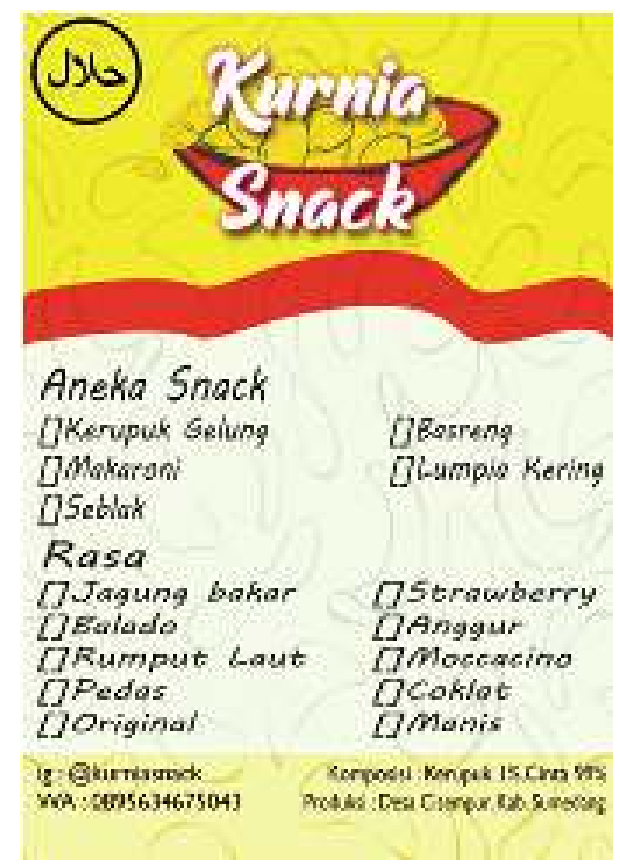

Gambar 1.1 Salah Satu Produk Kurnia snack (Makaroni manis)

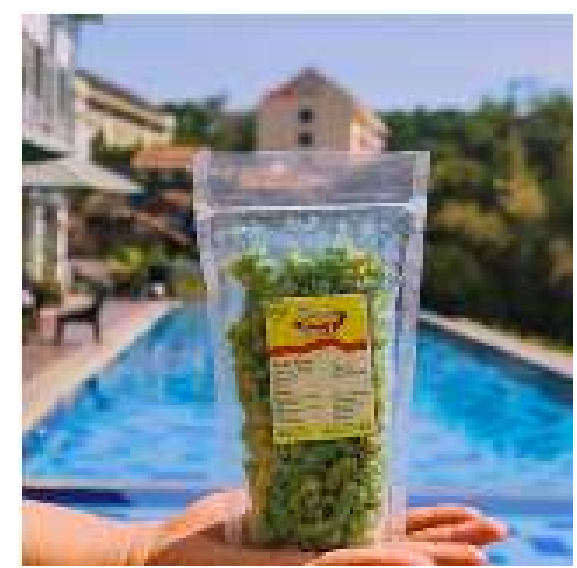

Gambar 1.2 Label Kemasan dari Kurnia Snack 


\section{Keunikan Produk}

Sebagaimana yang telah diketahui bahwa Seblak Kering Kurnia Snack ini bukanlah suatu usaha yang benar-benar baru berada di pasaran. Oleh karena itu, kami mencoba untuk membuat Kurnia Snack ini menjadi suatu bentuk usaha yang berbeda dengan usaha satu jenis lainnya. Keunggulan dari produk tersebut adalah: 1) Memiliki varian rasa yang lebih banyak dibandingkan produk camilan pada umumnya, tapi pada seblak kurnia ini tersedia variant rasa yang manis seperti makaroni rasa coklat, pandan, dan stroberi.2) Aman dan bisa di konsumsi oleh berbagai kalangan dan ragam usia, karena memiliki variant rasa pedas dan manis 3). Harga yang terjangkau.4)Diolah dengan bahan-bahan pilihan sehingga proses produksi nya terjamin higienis

\section{Pangsa Pasar}

Adanya beragam macam jenis kerupuk dan banyaknya varian rasa membuat Seblak Kurnia ini dapat dinikmati oleh berbagai kalangan dan beragam usia. Oleh karena itu target pasar dari produk ini adalah semua kalangan baik anak-anak sampai orang dewasa, pelajar, mahasiswa, karyawan, dan lain sebagainya. Untuk merealisasikan target, kami menentukan lokasi outlet berdekatan dengan tempat keramaian yang sering dilalui banyak orang. Selain itu, kami juga akan melakukan strategi pemasaran online, melalui website dan instagram.

\section{Lokasi Usaha}

Lokasi usaha menjadi salah satu hal yang penting untuk menunjang perkembangan usaha . Dalam penentuan lokasi usaha, hal-hal berikut yang harus dipertimbangankan : Lokasi yang strategis, dekat dengan sekolah, kampus, dan tempat ramai lainnya dan tidak terlalu sulit dalam menjangkau alat dan bahan produksi.

Pendampingan yang dilakukan kepada $\mathrm{Bu}$ heni Pengusaha seblak kering menjadi bahan diskusi bagi para peserta KKN bahwa mayarakat desa Cisempur masih belum mempunyai jiwa kewirausahaan yang kuat, sehingga perlu dilakukan pemberdayaan jiwa kewirausahaan secara komperhensif dan kontinue. Tapi karena waktu pengabdian terbatas, maka kami melakukan talkshow pemberdayaan jiwa kewirausahaan hanya 1 hari, bertempat dibalai desa Cisempur. Talkshow diisi oleh para narasumber yang pengalaman di bidang kewirausahaan termasuk dari Orange Unpad. Peserta Talkshow ada sekitar 50 orang terdiri dari para ibu2 PKK, para wirausaha dan perwakilan masyarakat dari tiap RW. 
Pelaksanaan talkshow cukup dinamis dan menarik, para narasumber sangat kompeten dibidangnya, dan mampu merangsang semangat para peserta untuk berwirausaha. Para peserta juga dalam sesi tanya jawab merespon dengan pertanyaam pertanyaan yang berbobot.

\section{KESIMPULAN}

Kegiatan KKN Tematik Kewirausahaan di Desa Cisempur memberikan dampak positif sehingga terdapat interaksi aktif berupa simbiosis mutualisme antara pihak akademisi dalam hal ini mahasiswa serta masyarakat setempat. Sehingga dapat memberikan informasi dan gambaran umum kepada mahasiswa dalam mengetahui kehidupan nyata di masyarakat. Adapun kepada pihak masyarakat merasa terbantu oleh masukan-masukan dari pihak akademisi.

sosialisasi Pemberdayaan kewirausahaan menimbulkan kesadaran serta jiwa kewirausahaan pada diri mahasiswa maupun masyarakat guna siap bersaing pada era percepatan ilmu pengetahuan dan teknologi ini.

Rekomendasi yang dapat kami berikan kepada masyarakat Desa Cisempur adalah pemanfaatan internet yang tengah pesatnya guna mengejar ketertinggalan pada pasar digital. Juga sangat diharapkan meningkatnya kepercayaan diri pada setiap wirausaha yang tengah merintis usahanya.

\section{DAFTAR PUSTAKA}

D Kasali, Rhenald dkk. 2012. Kewirausahaan. Hikmah : Jakarta.

Kumorohadi, Untung \& Nurhayati. 2010. “Analisis Kualitas Pembinaan dan Pengembangan Jiwa Kewirausahaan di Kalangan Mahasiswa". Unsud : Purwokerto.

Meredith, G. Geoffrey et al. 1996. Kewirausahaan Teori dan Praktek. PT Pustaka Binaman Pressindo : Jakarta.

Suryana, 2006. Kewirausahaan. Salemba 4 : Jakarta. 